\title{
IT DEPENDS ON WHAT YOU SHARE: THE ELUSIVE COST SAVINGS FROM SERVICE SHARING
}

\author{
Austin M. Aldag \\ Cornell University, \\ Mildred E. Warner \\ Cornell University, \\ Germà Bel \\ Universitat de Barcelona
}

\begin{abstract}
:
Inter-municipal cooperation is the most prevalent alternative service delivery method for US local governments. While aspirations for budgetary savings are one motivating factor, increased service quality and regional coordination are also important goals. We use an original 2013 survey of local governments in New York State to assess the level of service sharing and outcomes. We match our survey with twenty years (1996-2016) of service-level costs data to explore the relationships between sharing and costs across twelve common local government services. Our multivariate time series regressions find that service sharing leads to cost reductions in solid waste management, roads \& highways, police, library, and sewer services; no difference in costs for economic development, ambulance/EMS, fire, water, and youth recreation; and higher costs in elder services and planning \& zoning. These differences are explained by whether services have characteristics such as asset specificity and the ability to achieve economies of scale on the one hand, or if sharing leads to greater administrative intensity or quality and regional coordination outcomes on the other hand. We also analyze the effect of sharing on service costs over time, and find solid waste management, roads \& highways, police, and library are the only services where costs show a continued downward trend. Because cost savings are elusive, public sector reformers should be careful not to assume cost savings from sharing.
\end{abstract}

Keywords: shared services; inter-municipal cooperation; transaction costs; local government, cost savings

Prepared for delivery at the Workshop on the Ostrom Workshop (WOW6) conference, Indiana University Bloomington, June 19-21, 2019.

(C) Copyright 2019 by authors 


\section{Introduction}

Municipal boundaries are often suboptimal regarding the provision of local public services. The possibility of engaging in inter-municipal cooperation (i.e. "shared services") to deal with these problems was suggested almost sixty years ago by Ostrom, Tiebout and Warren (1961), when they pointed out the possibility that small municipalities could act jointly to provide services by means of different types of arrangements.

Despite the equity concerns of such a fragmented local government landscape (Lowery 2000), inter-municipal cooperation for the delivery of local public services has gained increasing attention (scholarly as well as in public policy) as a tool for local government reform (Feiock 2007: 2009: 2013). Shared services are now more common in the United States (US) than for-profit contracting (Homsy and Warner 2014). However, while many argue that sharing is an efficiency reform to reduce overall service costs, the relationship between inter-municipal cooperation and costs is still unclear.

Inter-municipal cooperation is presented as an alternative to regional consolidation to enhance local service efficiency (Elston and MacCarthaigh 2016). Because the decentralization of local government services - such as road and highway maintenance, fire and social services - is much higher in the US compared to European local governments, the US debate has placed strong emphasis on issues related to service quality and regional equity. This helps to clarify the greater emphasis placed on externalities in the US literature as compared to the emphasis on costs in the European literature on cooperation (Bel and Warner 2015; 2016). A meta-regression on the factors driving inter-municipal cooperation found a total of 49 published and unpublished multivariate 
analyses as of 2013; 38 of which had been conducted for the US (either the whole country, or specific states), with only 11 for the rest of the world (Bel and Warner 2016).

When US scholars study shared service delivery, they are more likely to focus on coordination and quality concerns (Hefetz and Warner 2002, Thurmaier and Wood 2004, Holzer et al. 2009) than on the possibilities of achieving greater efficiency and cost savings (Zeemering 2018, Holzer and Fry 2011). A meta analysis of US scholarship shows that cost savings as a result of shared services are found about half the time (Holzer and Fry 2011) and these savings may not endure over time (Aldag and Warner 2018).

As far as we are aware, to date no multivariate empirical analysis has been conducted evaluating the effect of cooperation on costs in the US. This is in stark contrast with the literature in Europe. For instance, a meta-analytic study of US and European literature on cooperation and costs found eight multivariate studies until 2013, all conducted for European countries (Bel and Warner 2015). Since then, several more studies are available, but all are for European countries as well.

With this paper, we seek to fill this gap in the literature, providing a longitudinal analysis of the effects of cooperation on public service costs in the US. We use information obtained from a 2013 survey we conducted of all municipalities and counties in New York State (NYS), excluding New York City. Our first contribution to the literature is to conduct the first multivariate study of cooperation and costs for local governments in the US. A second contribution is that our study goes far beyond one sector, and measures a wide range of services in a disaggregated analysis something the literature calls for (Feiock 2013; Elston and Dixon 2019; Zeemering 2018 ). All 
quantitative studies thus far, focus on a single service, ${ }^{1}$ but our analysis includes a total of twelve commonly provided local services and a database of service costs which spans twenty years (19962016). We can study the effect of cooperation on costs in each of these services, and explain why different services show different results. Finally, we can examine the nature of the effect of service sharing on costs over time given the structure of our panel data.

The rest of the study is organized as follows. First, we review the theoretical background on cooperation and costs, and then review the related empirical literature. Next we present our empirical strategy: model, data and analysis. This is followed by a post-hoc analysis of sharing on costs over time. We then discuss our results, and conclude with calls for future research.

\section{Why Share: Cost Savings or Broader Outcomes?}

Cost savings are a common motivator of cooperation (Holzer and Fry 2011, Bel and Warner 2016, Elston and MacCarthaigh 2016; Allers and de Greef 2018). With rising local government fiscal stress, there has been increasing policy interest focused on cost savings from cooperation (Kim 2018; Bel and Warner 2015). For example, New York State recently began to incentivize sharing by matching any savings from sharing with state financial assistance to reduce the local property tax burden (Aldag, Warner and Kim 2018). This narrow focus on just cost savings has been shown empirically to be related to short term term sharing agreements (Aldag and Warner 2018). Longer term considerations of service sharing (e.g. the positive externalities of expanding service

\footnotetext{
${ }^{1}$ The study conducted for Italy by Garrone, Grilli \& Rousseau (2013) included water, electricity and gas, and solid waste. However, these were not treated as individual services, but rather as services jointly provided by multiservice firms, which were the unit of analysis. A recent study in the Netherlands (Allers and Greef, 2018) includes estimations for three services: welfare services, garbage collection and tax collection.
} 
coverage, increasing service quality, and improved regional coordination) are typically given more weight in the US literature (Hefetz and Warner 2002, Holzer and Fry 2011, Bel and Warner 2015). Indeed, Thurmaier and Wood (2004) argue that cost savings are not the primary motivator of cooperation between US local governments.

Achieving scale economies is the primary theoretical basis for cost savings from shared services. When economies of scale exist, average cost decreases as production increases, but only up to a point. For instance, Stevens (1978), in a study of refuse collection, found economies of scale were fully exhausted at population of 50,000. When a jurisdiction is suboptimal for the delivery of a specific service, engaging in cooperation with other municipality(ies) allows aggregation of demand, which can then be served at a lower average cost. Potential cost savings can result from larger volumes of service being delivered by the production unit, or by reducing the staff and equipment needed to provide the same level of service (Dollery and Fleming, 2006: 274-275; Boyne 1995). Scale economies can be more appealing for smaller municipalities, whereas municipalities already operating at optimal scales can perceive more limited benefits from sharing services. Indeed, most studies find a negative relationship between shared services and population size (Bel and Warner 2016).

Diseconomies of scale have also played a role in the discussion on scale effects. Diseconomies of scale may result when the costs of coordination and communication increase with the scale of the activity due to an increase in administrative intensity (Elston and Dixon 2019). For example, large organizations may suffer from 'bureaucratic congestion' (Boyne, 1995). A recent study by Elston and Dixon (2019) on English municipalities, found administrative intensity did not fall with shared services. They argue UK local governments did not face many administrative scale diseconomies, 
and this explains why savings from Shared Service Centers could not be found. The initative also involved high transaction costs, something Williamson (1967) warned of long ago. Dollery and Fleming (2006: 280) emphasize that many analyses can be distorted by the fact that economies of scale can coexist with diseconomies of scope (those related to the effects of joint production of different services), and vice-versa.

There are a variety of reasons cost reductions from shared services would not be present. These include: start-up costs, transaction costs, improvements in service quality, increased administrative intensity and functional duplication (Bel and Warner 2016; Elston and MacCarthaigh 2016; Elston and Dixon 2019). Some sharing is used to provide redundant coverage to ensure fail safe delivery (Miranda and Lerner 1995). There is a wide literature on transaction costs and the challenges of contract management and monitoring under alternative service delivery (Warner and Hebdon 2001; Brown and Potoski 2003a, 2003b; Johnston and Girth 2012; Hefetz and Warner 2012; Kim 2018). These studies differentiate inter-municipal cooperation from for-profit contracting and show cooperation may have lower transaction costs, especially in asset specific services, due to more similar objectives between principal and agent when both parties are local governments. Where transaction costs are high, for-profit contracting has been found to be less likely to show cost savings (Bel, Fageda and Warner 2010). In shared services, timing can affect costs with early innovators facing higher transactions costs (Dollery and Grant 2010). Andrews and Boyne (2011) caution about the disruptive effects of organizational change. Longevity of shared service agrements is explained, in part, by the decline in transaction costs as agreements mature. Early stage agreements require testing and evaluation, whereas longer term agreements build trust and institutional formality (Aldag and Warner 2018). 
Ostrom (1972: 486) proposed that service sharing would be associated with more efficient provision of services depending on the type of public goods or services being considered. An initial distinction can be made between labor-intensive consumer-oriented services and technical services (Dollery and Fleming, 2006). In consumer-oriented services, inputs and activities of citizens affect the quality of services and can raise costs with sharing (Ostrom and Ostrom, 1977), as found with volunteer fire departments in New York State (Donahue 2004). By contrast, Andrews (2013) found scale economies in labor intensive education services in England, but cautioned there was a ushaped cost curve, so the specific aspects of service type matter. Technical services with asset specific elements, may benefit from economies of scale if there is slack, e.g. these assets are not fully utilized. Bel (2013) found evidence for economies of scale in urban transportation, airports, water and solid waste.

Hefetz and Warner (2012) and Zeemering (2018) have both shown that place characteristics also matter. Localities might be positioned to ride the economies of scale curve downward towards cost reductions if there is slack in the system for asset specific elements of the service. However, early innovators may face higher costs due to institutional design factors (Dollery and Grant 2010).

Broader outcomes of service sharing are also important to understand service costs. The literature makes a differentiation for services where coordination across the region and ensuring high quality may be a primary motivator of service sharing (Holzer and Fry 2011). In such cases, the costs of sharing could be higher than not sharing because the desired outcomes are about enhancing service quality and regional equity (Bel and Warner 2016; Elston and MacCarthaigh 2016; Warner 2011; Hefetz and Warner 2002). 
Studies of services that have greater regional scope (such as planning, environmental management, and social programs) give consideration to a much broader range of outcomes of sharing. For example, in a study of watershed management and environmental outcomes Scott (2015) shows that collaborative groups achieve better quality service outcomes and that groups that have been in place for a longer period of time achieve lower levels of pollutants. Girth et al. (2012) found that cooperation is higher in the US in waste management, transit and social services. Health, youth and elder services often benefit from regional coordination to enhance access, especially when coverage of these services is low in suburban and rural communities (Warner, Homsy and Morken 2017). In a systematic review of the literature regarding social work and aging services, Rizzo and Rowe (2016), show that more studies focus on quality of life outcomes than documented cost savings.

Given the broader range of desired outcomes of service sharing than just economies of scale and the differentiation between services and across place, we anticipate dissimilar results across our set of twelve services. The findings of this analysis will inform the literature.

\section{Empirical Evidence on Cooperation and Costs}

Empirical evidence on cooperation and costs in the US is limited primarily to case studies. Holzer and Fry (2011) conducted a meta-analytic review of US studies of cooperation and costs and reported cost savings are found about half the time. In a recent study of collaborative police contracts in California, Zeemering (2018), examined seven local governments between 1999 and 2015 and found mixed results, with three cases showing cost reductions post-sharing and four cases showing increased costs. 
No multivariate empirical analysis on the effect of cooperation on costs over time has been conducted in the US. By contrast, this type of study began to be published for European countries by the mid-2000s and empirical analyses on cooperation and costs have inceased in the current decade. For example, early empirical evidence of cooperation on costs in solid waste in municipalities in Catalonia (Spain) showed no effect of private production on costs, but intermunicipal cooperation was significantly associated with lower costs, especially for smaller municipalities (Bel and Costas 2006). Sørensen (2007) analyzed the effect of cooperation on fees paid per household in Norway and found that cooperation significantly increased fees. But the average size of municipalities in Norway is much larger than in Spain. More recently Bel \& Mur (2009) studied solid waste collection in Aragon (Spain), where most municipalities have a very low population, and found significant costs savings from cooperation.

Academic publications on cooperation and costs have dramatically expanded in the current decade. Since 2013, about 25 studies have been published on the topic, for many European countries (Spain, Norway, The Netherlands, the United Kingdom, Germany, Italy, France, Czech Republic and Sweden). Most of the studies deal with solid waste collection, but more recent studies examine other services. For instance, Elston and Dixon (2019) on administrative services, Holmgren and Weinholt (2016) and Blåka (2017) on fire service; Niaounakis \& Blank (2017) on tax collection, and Blaeschke and Haug (2018) on wastewater. Garrone et al (2013) analyze multi-service firms delivering waste, electricity, natural gas and water. Other studies deal with three services (Allers and de Greef, 2018), or the municipality as a whole (Frère, Leprince and Paty, 2014); Ferraresi, Migali and Rizzo, 2018). Yet, a comprehensive analysis across a wide variety of services has yet to be conducted. 
Most of these studies (i.e. Dijkgraaf and Gradus, 2013, 2014; Zafra-Gómez et al, 2013; Bel et al, 2014; Soukopovà et al, 2016; Soukopovà and Klimovský, 2016; Blåka, 2017; Allers \& de Greef 2018; Soukopová and Vaceková, 2018) use cost functions similar to that in Bel and Costas (2006). However, other estimation techniques have been recently applied, such as translogarithmic cost functions in Garrone et al (2013) for Italy, Data Envelopment Analysis by Blaeschke and Haug (2018) for Germany, metafrontier techniques by Pérez-López et al (2016) for Spain, and data envelope analysis panel data estimations by Pérez-López et al (2018) for Spain.

Most recent studies find cost savings from cooperation in solid waste collection. Tax collection in the Netherlands also shows cost savings for cooperation in smaller municipalities (Niaounakis and Blank, 2017). In other sevices, higher costs are sometimes found. For multiservice firms in Italy (Garrone et al 2013) and wastewater in Germany (Blaeschke and Haug, 2018) cooperation is associated with lower efficiency, although Blaeschke and Haug (2018) also find that smaller municipalities can benefit from scale economies. For fire services in Sweden (Holmgren and Weinholt, 2016) and Norway (Blåka, 2017) inter-municipal cooperation does not show systematic effect on costs overall. However, Blåka (2017) also finds that inter-municipal corporations $^{2}$ with more member govenments show higher costs, due to the greater organizational transaction costs. This is similar to results found by Elston and Dixon (2019) in English shared service centers.

\footnotetext{
${ }^{2}$ Inter-municipal corporations are single organizations that have their own capacities and resources, and their management is subordinated to a board formed with representatives of the participating municipalities (Hulst and van Montfort 2012).
} 
From this review of the existing empirical evidence, we can draw two observations. First, that studies conducted in environments with lower average population are more prone to show cost savings from cooperation. Second, and more important for our purposes, differences across services - based on service characteristics - might explain why results on cooperation and costs diverge.

\section{Empirical Strategy}

\section{3a Data and Methodology}

Our data are drawn from two primary sources: a local government survey we conducted of all municipalities in New York State in 2013 and annual cost data for each service for each local government provided by the New York State Comptroller's Office. Our survey assessed service sharing among townships, cities, villages and counties across New York State. New York City was excluded because its scale is so large that sharing outside its borders is uncommon. The survey had an excellent response rate: $58 \%$ of the 1,607 local government in the state responded.

The survey asked local government officials a variety of questions regarding sharing, motivators, outcomes and barriers. In this study, we analyze twelve services which match categories for which the New York State Comptroller has collected cost data for all localities since 1996. The services are the following: solid waste management (which includes garbage collection \& landfill), roads \& highways, water, sewer, elderly services, youth recreation, library, police, fire, ambulance/Emergency Medical Services (EMS), economic development administration and promotion, and planning and zoning. These services were defined based on focus groups with local 
officials to be service areas where sharing was most common. The implicit price deflator was used to bring all service costs to 2013 constant dollars to control for inflation.

Survey respondents were first asked to indicate if their locality provided the service. If yes, then the survey asked if the service was shared, and if shared, which of the following outcomes were achieved: 1) "cost savings," 2) “improved service quality,” and 3) “improved cross-jurisdictional service coordination."

Table 1. Levels of Service Sharing and Outcomes

\begin{tabular}{|c|c|c|c|c|c|c|}
\hline Service & Provided & Shared & $\begin{array}{l}\% \text { Cost } \\
\text { Savings }{ }^{1}\end{array}$ & $\begin{array}{l}\text { \%Increased } \\
\text { Quality }^{1}\end{array}$ & $\begin{array}{l}\% \text { Improved } \\
\text { ICoordination }^{1}\end{array}$ & $\begin{array}{c}\text { Average } \\
\text { Years } \\
\text { Shared }^{1}\end{array}$ \\
\hline Fire & 625 & 336 & $51 \%$ & $61 \%$ & $51 \%$ & 34.0 \\
\hline Ambulance/EMS & 495 & 290 & $50 \%$ & $66 \%$ & $48 \%$ & 25.9 \\
\hline Sewer & 463 & 172 & $45 \%$ & $53 \%$ & $38 \%$ & 25.5 \\
\hline Library & 359 & 188 & $47 \%$ & $60 \%$ & $38 \%$ & 23.2 \\
\hline $\begin{array}{l}\text { Youth } \\
\text { Recreation }\end{array}$ & 645 & 316 & $55 \%$ & $65 \%$ & $45 \%$ & 21.9 \\
\hline Water & 568 & 214 & $50 \%$ & $57 \%$ & $45 \%$ & 21.5 \\
\hline $\begin{array}{l}\text { Roads and } \\
\text { Highways }\end{array}$ & 855 & 412 & $72 \%$ & $63 \%$ & $53 \%$ & 20.4 \\
\hline Police & 359 & 105 & $57 \%$ & $57 \%$ & $43 \%$ & 20.2 \\
\hline Elder Services & 317 & 118 & $36 \%$ & $67 \%$ & $45 \%$ & 19.5 \\
\hline $\begin{array}{l}\text { Solid Waste } \\
\text { Management }\end{array}$ & 463 & 121 & $70 \%$ & $58 \%$ & $43 \%$ & 17.2 \\
\hline $\begin{array}{l}\text { Planning and } \\
\text { Zoning }\end{array}$ & 718 & 77 & $58 \%$ & $63 \%$ & $60 \%$ & 15.8 \\
\hline $\begin{array}{l}\text { Economic Dev } \\
\text { \& Promotion }\end{array}$ & 294 & 108 & $39 \%$ & $59 \%$ & $68 \%$ & 15.4 \\
\hline
\end{tabular}

Source: New York State Shared Services Survey, 2013. N=946 local governments.

As seen in Table 1, fire, ambulance/EMS and library services are provided via inter-municipal cooperation by more than half of responding local governments. Solid waste management and roads and highways indicate the highest levels of reported cost savings. Improved service quality is reported more often than cost savings. Service quality and regional coordination are reported at 
the highest levels in planning and zoning, elderly services and economic development. These features may help explain differences in cost savings. Furthermore, the average duration of cooperation in the services included on our survey was 20 years. Fire was provided via cooperation the longest (mean of 34 years), and economic development the shortest (15.4 years).

Among New York States almost 1600 local governments, the history of service sharing is long. Fire departments, many of which are volunteer (Donahue 2004), have had mutual aid agreements in force since after World War II. The same is true of highway and roads departments where equipment sharing and mutual aid after big snow storms or floods is quite common. Similarly in libraries, regional systems for book sharing have been created to support smaller rural libraries. Communities are encouraged to create a regional bureau (often at the county level) where local governments can coordinate elder and youth services and ensure service access to clients in outlying areas. Economic development and planning and zoning are service areas where interjurisdictional competition is recognized as an impediment to economic growth and cooperation is less common. Climate change and an aging society have increased the importance of planning and zoning and elder services in recent years, prompting the state to encourage service sharing to enhance the quality of services and access, especially in smaller suburban and rural communities.

Not all localities provide the same bundle of services. Cities and villages, as urbanized areas, are more likely to provide water and sewer services and have police departments, but all local governments provide road and highway services. Fire service is provided by volunteer fire districts and may involve contracts with towns and villages, whereas city fire departments are more likely to be professional and unionized. The same is often true of ambulance and EMS service. City and county police departments are also more likely to be unionized, whereas village police departments 
are not. To account for the greater formality in urban services and greater likelihood of unionization, we include a control dummy variable for cities in our cost models.

Lastly, we supplement our survey data with demographic data drawn from the 2010 US Census, the American Community Survey (ACS; 5-year estimates 2009-2013), as well as fiscal data which covers twenty years of cost data (1996-2016) for each particular service from the NYS Comptroller's Office. The average duration of the intermunicipal cooperative arrangements in our panel data is from 15 to 34 years, thus, even the shortest sharing period commences prior to the start of our cost series.

\section{The Model and Variables}

Following most empirical studies, the basic function for municipal service costs can be represented as:

$$
\mathrm{C}=f(\mathrm{Q}, \mathrm{X}, \mathrm{Z})(1)
$$

$\mathrm{C}$ is the total costs of the service for the locality. These are mainly determined by (1) the level of output Q; (2) non-controllable characteristics X already affecting the service; and (3) the choice Z for service delivery. Explanatory variables considered here are the following:

Population: We take the population for each local government which serves as a proxy for level of output, as specific data for output are not available. This data is taken from the 2013 American Community Survey (ACS) 5-year averages (2009-2013). We expect total costs will have a positive relationship with population size. 
Population density: We include inhabitants per square mile in the model to take account of potential economies (diseconomies) of density related to the dispersion/concentration of population in the locality. This measure is also derived from ACS data. The expected effect of density is ambiguous and is expected to differ across the twelve services in this study. On the one hand, a greater degree of concentration of the population offers the possibility of enjoying economies of density. On the other hand, some services may be subject to congestion costs, which are positively associated with population density. Both effects act in opposite directions, making it difficult to predict the effect of population density on expenditures.

City: Costs of service delivery also can be affected by the level of urbanization. Cities are expected to provide a higher number and level of service, and they tend to have more professionalized labor and management, and higher levels of unionization. To account for the greater formality in urban services and greater likelihood of unionization, we specify city as a dummy variable (1 if City; otherwise 0 ). We expect costs to be positively associated with City.

Shared Service: The key variable of interest in our analysis is if the service was provided by a sharing arrangement. We include a dummy variable that equals 1 when survey respondents indicated the service was "provided in a sharing arrangement" (otherwise 0 ).

While we do not have a precise set of hypotheses for every single service, we expect that services more likely to show lower costs will have asset specific elements (specialized personnel and equipment) which have some slack, so that economies of scale are present. These would include roads and highways, solid waste, sewer, water, police and libraries. Generally, in services where quality and regional coordination are more common objectives, we expect cost savings may not be 
found. These would include youth recreation, elder services, economic development and planning and zoning. Fire and ambulance/EMS exhibit a wide variety in organizational form of delivery (volunteer, paid and unionized) and a very long history of sharing. This variety in organizational form could raise transaction costs of sharing, but the long terms of sharing could lower these organizational transaction costs over time. Thus we do not have a strong expectation regarding results. See Appendix Table 1 for descriptive statistics of all model variables for each of the twelve services.

\section{Empirical Implementation and Results}

Based on the cost function introduced above (1), we specify a time series model of the following types for the services that we study:

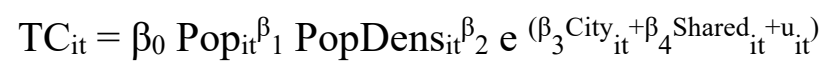

All variables have been defined above, and $u_{i}$ stands for the error term. As is frequent in analysis of the costs of local services (see Bel et al. 2010), we estimate the double logarithmic form of the equation. Note that by estimating a double logarithmic form, $\beta_{1}$ is the elasticity of costs with respect to our proxy for output. Therefore, it gives us information about potential scale economies across the services under consideration. Also, a random-effect model is used for the time series equation, as no independent variables vary by year. Service costs are determined by the unit of local government which provides the service and the intercepts of the regression lines are allowed to vary by locality. For each model we have both an $\mathrm{N}$ for the number of observed governments $(\mathrm{N}=5,787$ across all models because many governments provide a number of the 
services) and also the number of observations of service cost included in the model $(\mathrm{N}=110,220$ across all twelve models).

$$
\log \mathrm{TC}_{\mathrm{it}}=\beta_{0}+\beta_{1} \log \mathrm{Pop}_{\mathrm{it}}+\beta_{2} \log \mathrm{PopDenS}_{\mathrm{it}}+\beta_{3} \text { City }_{\mathrm{it}}+\beta_{4} \text { Shared }_{\mathrm{it}}+\mathrm{u}_{\mathrm{it}}
$$

Table 2 presents the results obtained from the estimation of equation (3) for each of the twelve services for which we have full information drawn from our survey and Comptroller service cost data. Because the shared dummy variable is the main focus of our analysis, we present this variable in the first row. Variation inflation factors were calculated to ensure multicollinearity was not present; the highest mean VIF for the models was 1.33.

As seen in Table 2, model results show variation in how sharing affects service costs across all twelve services. As expected, population is positively associated with costs in all services. However, scale economies differ between services. Most services show economies of scale $\left(0<\beta_{1}\right.$ $<1)$ : economic development, EMS, fire, solid waste management, roads and highways, sewer, water and youth recreation. In police and library services $\beta_{1}$ is very close to one so that we cannot clearly say there are economies or diseconomies of scale. In these services, some elements enjoy economies of scale - dispatch and 911 service, sharing books across libraries - and others are purely local - road patrol and local library branches. Diseconomies of scale $\left(\beta_{1}>1\right)$ are found for elderly services and planning \& zoning. But these are services where quality and coordination are important outcomes of sharing. Regarding population density, it shows a positive and significant effect for most services, although the opposite is found for elderly services, planning \& zoning, and roads \& highways. Density is insignificant on costs for economic development, and ambulance 
/ EMS. The city dummy variable, a proxy measure for greater formality and unionization, shows a positive and significant effect on costs for most services, as expected. ${ }^{3}$

To calculate the explanatory value of these time series regressions, we first calculated the total amount of variation present in the unsaturated model and again after the model was fully saturated with the four variables. The difference between these two variances was used to calculate the explained variance which may be attributed to our models. The explanatory power of the estimations ranges from $30.76 \%$ in ambulance/EMS to $80.19 \%$ in roads and highways.

We now turn our attention to the most interesting variable for our purpose, the dummy variable that reflects shared services. As anticipated, there is variation in the relationship between cooperation and costs across all services. Lower costs with sharing is found in library, police, solid waste management, roads \& highways and sewer, as expected. Each of these services has asset specific elements which may offer economies of scale (shared collections, shared dispatch, shared facilities and equipment). Higher costs with sharing are found for elder services and planning \& zoning. These two services also report broader outcomes regarding service quality and regional coordination. No significant association is found between sharing and costs for six services (fire, ambulance/EMS, water, youth recreation and economic development). These services exhibit a wide aray of organizational forms which may affect the costs of sharing. These results show the importance of undersanding the potential sources of economies of scale, the potential transactions costs of coordination and the impact of broader objectives of quality and coordination.

\footnotetext{
${ }^{3}$ We also tested models where we included a control variable for the number of services provided by each local government (1-29). In these models sharing is also positively related to costs in ambulance/EMS, but no longer significant for solid waste management and sewer.
} 
Table 2: Time Series Model Results: Effects of Service Sharing on Costs (1996-2016) for NYS local governments

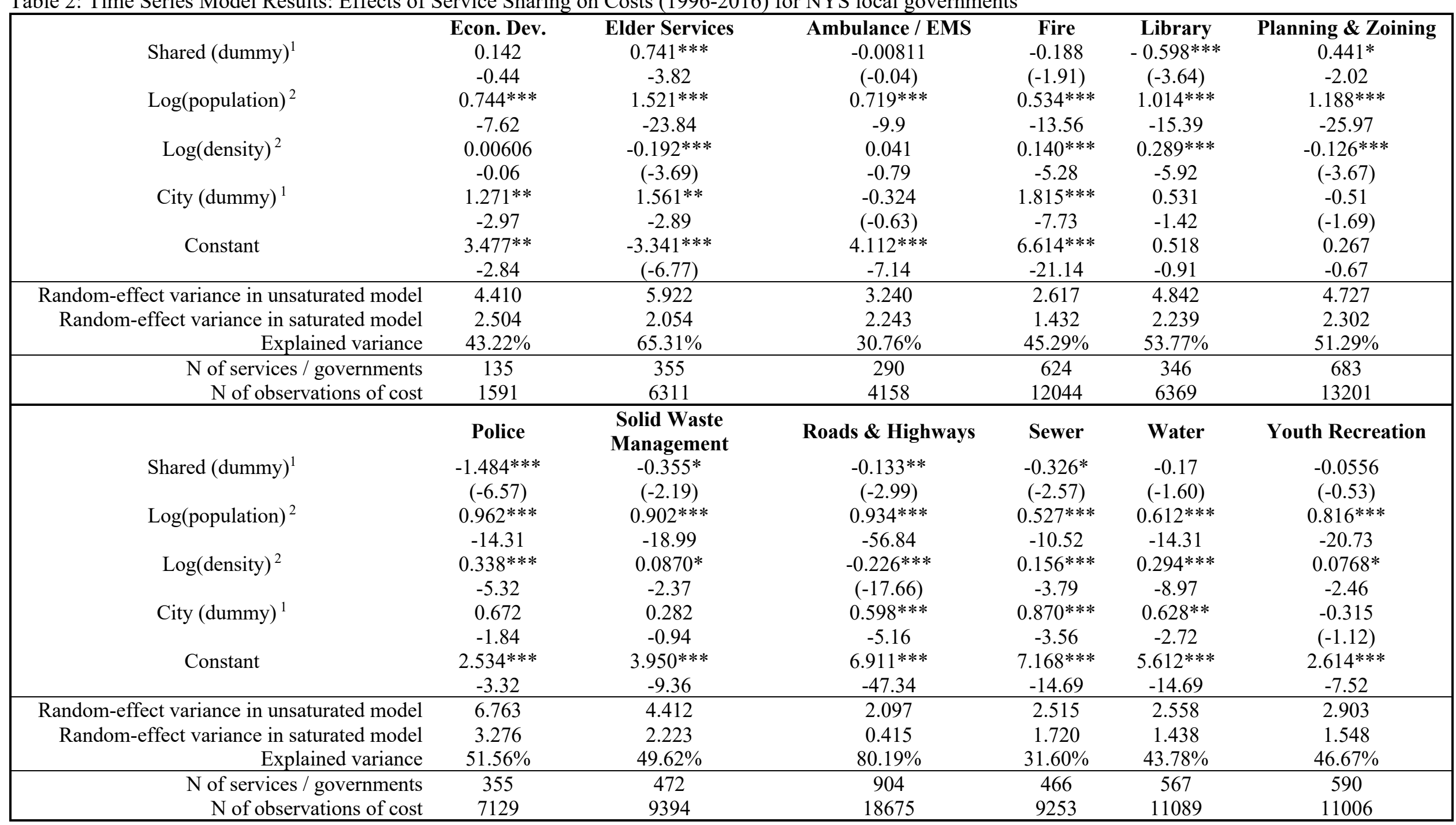

Notes: t-statistics in parentheses -- $* \mathrm{p}<0.05 ; * * \mathrm{p}<0.01 ; * * * \mathrm{p}<0.001$

Source: NYS Comptroller cost data (1996-2016), ${ }^{1}$ NYS local government shared service survey (2013), ${ }^{2}$ ACS) 5 -year averages (2009-2013). 


\section{Post-hoc Analysis: Sharing's Effect on Costs Over Time}

To test the robustness of our results and examine if the effect of sharing changes over time, the model (3) was disaggregated for each of the 20 years for the seven services for which sharing significantly corresponds with costs (either positive or negative), and was rerun in a cross sectional manner. Twenty models were run for each of the seven services (140 models in total) to examine if the magnitude of the sharing coefficient changes over time. The coefficients of the shared dummy variable for each year are shown in Figure 1.

Although the duration of sharing arrangements varies by service and by place, we only have data on if the service is shared, not the precise year when sharing started. Thus our estimate of the cumulative effect of sharing over time is a rough estimate comparing cost trends of places which shared the service with those that did not. This allows us to see if the cost of shared services rise over time and converge to the level of unshared services. Figure 1 shows these trends over time. The $y$-axis denotes the magnitude of the sharing coefficient (a zero indicates service costs of the same service if unshared). Each trend also includes its linear equation to show the slope and y intercept. 
Figure 1. Effect of Sharing on Costs (Overtime 1996-2016): NYS Local Governments

Police

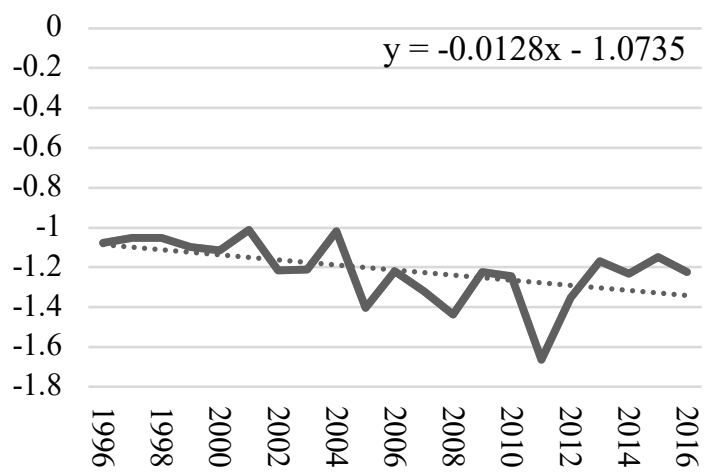

Solid Waste Management

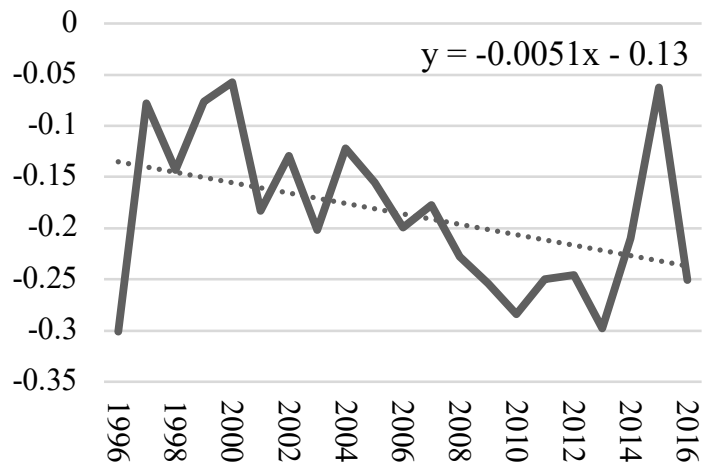

Library

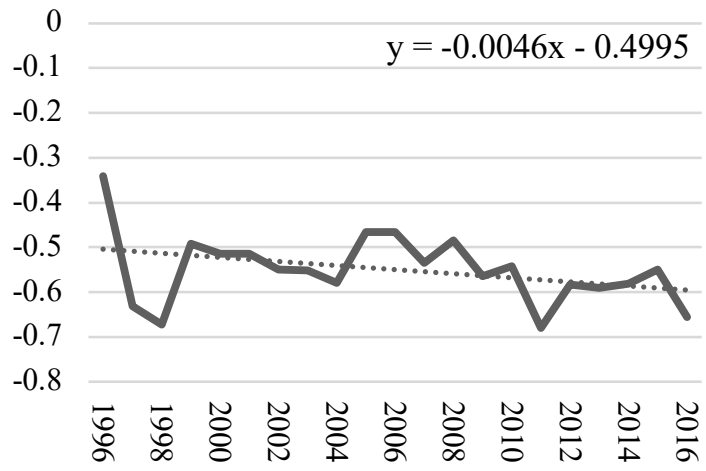

Roads \& Highways

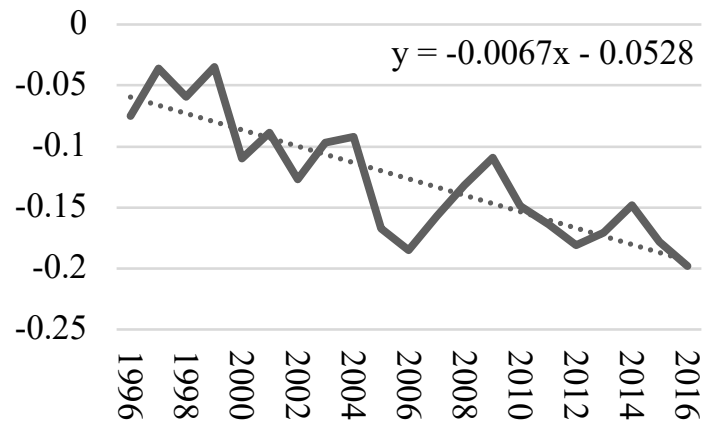

Sewer

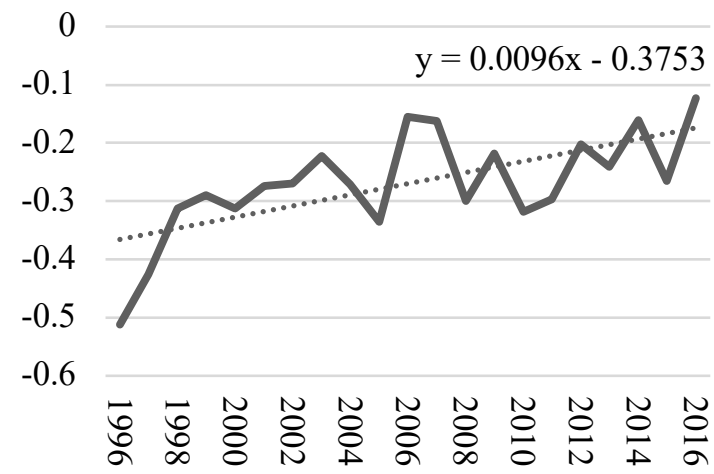

Elder Services

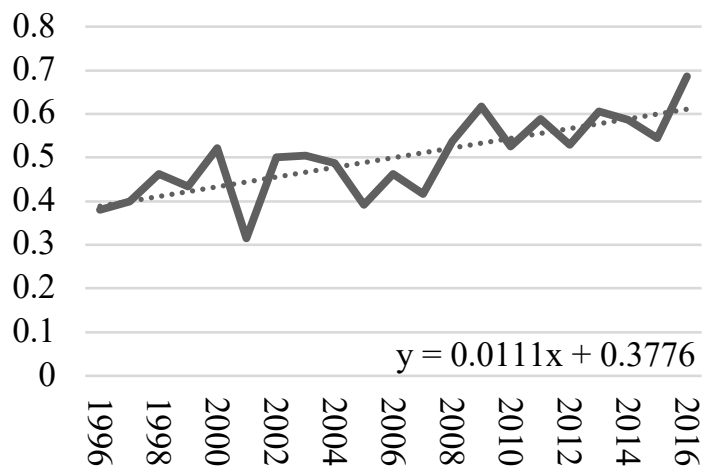

Planning \& Zoning

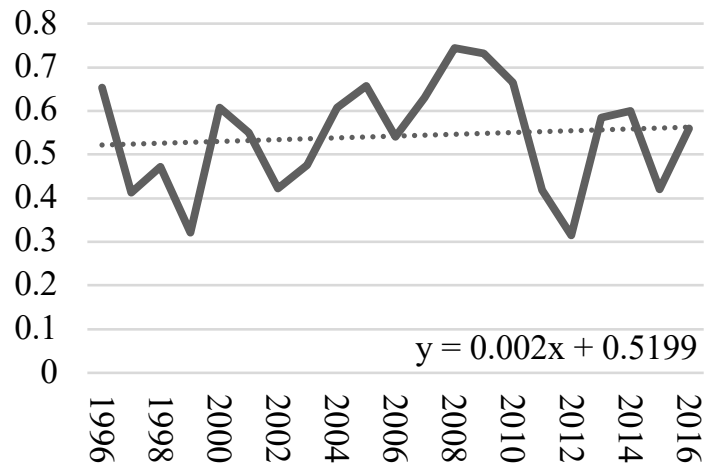

Source: NYS local government shared service survey (2013) and NYS Comptroller cost data (19962016). 
As shown in Figure 1, for all but sewer services, the services that show cost savings as a result of sharing exhibit a downward trend in costs over time. This means that the effect of the sharing variable is stronger at the end of the time period (2016), and costs diverge from that of unshared services. Sewer, on the other hand, is still cheaper with sharing, but the trend is upward and appears to be moving towards converging with unshared service costs.

As expected, service characteristics help differentiate this group of cost reductions from sharing. Many of these services have highly asset specific elements which are not fully utilitized and thus offer potential scale economies (e.g. police, solid waste, sewer, and roads). For example, of all sharing plans submitted statewide in $2016,62 \%$ of the projected savings came from a single shared wastewater treatment plant between the City of Long Beach and Nassau County (Rockefeller Institute 2017).

One challenge with shared services is how to control the costs of the organizational structure for the sharing. For roads and highways, this is often informal cooperation among peer deparments and organizational costs are quite low. For police, road patrols is kept local, and formal collaborations are focused on asset specific services like detectives and dispatch (911). In libraries, the state subsidizes regional institutions that facilitate sharing and this reduces costs for the local unit, which is what we measure.

By contrast, the twenty year trends for both elder services and planning and zoning, the two services which show higher costs as a result of sharing, remain positive and rise over time (which confirms our previous time series results). These are services where sharing results in improved quality and the organizational costs of sharing are borne within the local government unit. While quality and coordination are important goals of sharing, they can lead to increased costs over time. 
New York State has a large number of rural and suburban jurisdictions which engage in very limited provision of zoning or elder services. To encourage a higher level of service, the State encourages shared service arrangements, but it does not provide extra funding for organizing the sharing arnagements. Planning and zoning can be used to help smaller communities address the impacts of climate change (Homsy 2018) and enhanced elder services can help meet the needs of an aging society (Warner, Homsy and Morken 2017). Thus rising costs may be attributed to both a higher level of service and possible higher organization costs. Future research should look more closely at cases where service expansion, quality and coordination factors drive increased costs under cooperation.

\section{Discussion}

There is increasing interest in the analysis of the effects of inter-municipal cooperation on service costs, but the available evidence is still scarce, and either limited to a few European countries or single services. In this paper we have studied the relationship between cooperation and costs for local governments in New York State using a time series regression. In order to be able to have homogeneous - thus more comparable - cost estimations, we defined rather simple parsimoneous cost functions, which is a limitation of our study. Yet our time series model includes over 20 years of cost data to arrive at a robust set of results. Our analysis is much broader than previous studies and includes a comparison across twelve commonlyprovided local services with a standard set of models.

Our results indicate a negative effect (savings) of cooperation on costs in five services -police, library, solid waste management, sewer, and roads and highways. A common characteristic among these services is, their higher levels of asset specificity, tendency to achieve economies 
of scale and seek fiscal outcomes of sharing. The cost savings effects of cooperation are also consistent over time, for all but sewer services, across the twenty year analysis period.

By contrast, our results indicate that cooperation leads to higher costs in both elder services and planning and zoning, and in these services, the effects of sharing increases costs over time. We note that these two services are primarily motivated by broader concerns related to increased service quality and increased coordination. These broader goals are key concerns in public administration, especially as cities use planning and zoning to address the challenges of climate change and expand elder sevices to meet the needs of an aging society. These broader motivations and outcomes lead to higher service costs, not lower.

We found no difference in cost with sharing in economic development, water and youth recreation, ambulance/EMS and Fire. Water has limited economies of scale due to its fixed infrastructure. Youth recreation is a service with a highly variable level of output across communities, and shared services have been promoted by the State to help enhance services in communities that underprovide this service. Sharing in economic development has been encouraged to reduce destructive inter-local competition and promote coordination. Fire and ambulance/EMS face special organizational issues. In rural communities these services are primarily staffed by volunteers, whereas in cities they are professional, unionized services. Sharing is typically informal - backup support in the event of a major fire or accident, rather than a consolidated service. Future research should take into account the formality of the sharing arrangement, something we cannot do in this study. Future research should also attempt to control for the specific year when sharing began. This would require regular data on service form by year, something we cannot get based on recall in a single point in time survey. While most sharing is with near neighbors and these do not move over time, it would still be interesting to control for shifts in sharing partners, if possible. 


\section{Conclusion}

Overall, our results provide fresh insights into why the literature does not find consistent results on the the effect of cooperation on costs. Our comparison across twelve services shows cost savings are heavily dependent on the characteristics of each service. Our results show that basic economic concerns with asset specificity and economies of scale help explain why cost savings are found in some services and not in others. We find in most services, economies of scale are limited.

There are also the administrative costs associated with organizational design of service sharing itself. Public administration theory has given extensive focus to transaction costs at both the service and organizational level (Hefetz and Warenr 2012, Brown and Potoski 2003b). Feiock (2013) in his ICA framework has pointed to the high transaction costs of building and maintaining collaborative relations. Dollery and Gant (2010) have shown these costs can be especially high among early innovators. Transactions costs of sharing may decline over time (Aldag and Waner 2018), but when service sharing does not reduce administrative intensity, no cost savings are found (Elston and Dixon 2019).

Because the cost savings from service sharing are limited, policymakers should be cautious in their promotion of shared service reforms. If improved quality, professionalism and regional coordination are the primary goals, then higher costs with sharing should be expected. But if higher costs are driven primarily by the administrative costs of cooperation, then the costs of cooperation could outweigh the benefits. Shared services are no panacea. They may result in higher costs; but they also may help fragmented local governments achieve higher quality services. Policymakers should be clear about the desired goals of cooperation and realize economies of scale are more limited than popularly assumed. 


\section{References}

Aldag, Austin M. \& Warner, Mildred E. 2018. "Cooperation, Not Cost Savings: Explaining Duration of Shared Service Agreements." Local Government Studies 44(3): 350-370.

Aldag, Austin, Warner, Mildred E. \& Kim, Yunji. 2018. "Leviathan or Public Steward? Evidence on Local Government Taxing Behavior from New York State" Publius, forthcoming. DOI: 10.1093/Publius/pjy035

Allers, Maarten A., \& de Greef, J.A. Tom. 2018. "Intermunicipal Cooperation, Public Spending and Service Levels." Local Government Studies 44(1): 127-50.

Andrews, Rhys. 2013. "Local Government Size and Efficiency in Labour Intensive Public Services: Evidence from Local Educational Authorities in England," pp 175-192 in The Challenge of Local Government Size: Theoretical Perspectives, International Experience, and Policy Reform, ed. by Santiago Lago-Peñas and Jorge MartinezVazquez, Cheltenham, UK: Edward Elgar.

Andrews, Rhys \& Boyne, George. 2012. "Structural change and public service performance: The impact of the reorganization process in English local government." Public Administration, 90(2): 297-312.

Ansell, Chris \& Gash, Alison. 2008. "Collaborative Governance in Theory and Practice." Journal of Public Administration Research and Theory 18(4): 543-571.

Bel, Germà. 2013. "Local Government Size and Efficiency in Capital Intensive Services: What Evidence is There of Economies of Scale, Density and Scope?" Pp 153-173 in The Challenge of Local Government Size: Theoretical Perspectives, International Experience, and Policy Reform, ed. by Santiago Lago-Peñas and Jorge Martinez-Vazquez, Cheltenham, UK: Edward Elgar.

Bel, Germà \& Costas, Antón. 2006. "Do public sector reforms get rusty?: Local privatization in Spain.” Journal of Policy Reform 9(1): 1-24.

Bel, Germà, Fageda, Xavier \& Mur, Melania. 2014. Does Cooperation Reduce Service Delivery Costs? Evidence from Residential Solid Waste Services. Journal of Public Administration Research and Theory 24(1): 85-107.

Bel, Germà, Fageda, Xavier \& Mildred E. Warner 2010. "Is Private Production of Public Services Cheaper than Public Production? A meta-regression analysis of solid waste and water services," Journal of Policy Analysis and Management, 29(3): 553-577.

Bel, Germà \& Warner, Mildred E. 2015. "Inter-municipal cooperation and costs: Expectations and evidence." Public Administration, 93(1): 52-67.

Bel, Germà \& Warner, Mildred E. 2016. "Factors explaining inter-municipal cooperation in service delivery: A Meta-regression analysis." Journal of Economic Policy Reform, 19(2): 91-115.

Blaeschke, Frédéric \& Haug, Peter. 2018. "Does Intermunicipal Cooperation Increase Efficiency? A Conditional Metafrontier Approach for the Hessian Wastewater Sector." Local Government Studies 44(1): 151-71.

Blåka, Sara. 2017a. "Does Cooperation Affect Service Delivery Costs? Evidence from Fire Services in Norway." Public Administration 95(4): 1092-1106.

Boyne, George. 1995. Population Size and Economies of Scale in Local Government. Policy \& Politics 23(3): 213-222.

Brown, Trevor L. \& Potoski, Matthew. 2003a. "Managing Contract Performance: A transaction Costs Approach," Journal of Policy Analysis and Management 22 (2), 275-297.

Brown, Trevor L. \& Potoski, Matthew. 2003b. "Transaction Costs and Institutional Explanations for Government Service Production Decisions." Journal of Public Administration Research and Theory: 13 (4): 441-68. 
Dijkgraaf, E. \& Gradus, R.H.J.M. 2013. "Cost advantage cooperations larger than private waste factors". Applied Economics Letters 20(7): 702-705.

Dijkgraaf, E. \& Gradus, Raymond. 2014. "'Waste Management in the Netherlands. In Thomas Kinnaman and Kenji Takeuchi, eds., Handbook on Waste Management, Cheltenham: Edward Elgar Publishers, 287-315.

Dollery, Brain \& Fleming, Euan. 2006. A Conceptual Note on Scale Economies, Size Economies and Scope Economies in Australian Local Government. Urban Policy and Research 24(2), 271-282.

Dollery, Brian, E. \& Grant, Bligh. 2010. "Tortoises and Hares: The Race to Shared Services Across Austrialian State and Territory Jurisdictions." Interional Journal of Public Administration 33(1):43-54.

Donahue, Amy K. 2004. "The Influence of Management on the Cost of Fire Protection." Journal of Public Analysis and Management 23(1):71-92.

Elston, Thomas \& Dixon, Ruth. 2019. The Effect of Shared Service Centers on Administrative Intensity in English Local Government: A Longitudinal Evaluation. Journal of Public Administration Research and Theory, forthcoming.

Elston, Thomas \& MacCarthaigh, Muiris. 2016. "Sharing services, saving money? Five risks to cost-saving when organizations share services." Public Money \& Management 36(5): 349-356.

Feiock, Richard C. 2007. "Rational Choice and Regional Governance.” Journal of Urban Affairs 29(1): 47-63.

Feiock, Richard C. 2009. "Metropolitan Governance and Institutional Collective Action." Urban Affairs Review 44 (3): 356-377.

Feiock, Richard C. 2013. "The Institutional Collective Action Framework.” Policy Studies Journal 41(3): 397-425

Ferraresi, Massimiliano, Migali, Giuseppe \& Rizzo, Leonzio. 2018. "Does Intermunicipal Cooperation Promote Efficiency Gains? Evidence from Italian Municipal Unions." Journal of Regional Science forthcoming.

Frère, Quentin, Leprince, Matthieu \& Paty, Sonia. 2014. "The Impact of Intermunicipal Cooperation on Local Public Spending." Urban Studies 51(8): 1741-60.

Garrone, Paola, Grilli, Luca \& Rousseau, Xavier. 2013. Management Discretion and Political Interference in Municipal Enterprises. Evidence from Italian Utilities. Local Government Studies 39(4): 514-540.

Hefetz, Amir \& Warner, Mildred E. 2002. “Applying Market Solutions to Public Services: An Assessment of Efficiency, Equity and Voice." Urban Affairs Review 38(1):70-89.

Hefetz, Amir \& Warner, Mildred E. 2012. Contracting or Public Delivery? The Importance of Service, Market and Management Characteristics. Journal of Public Administration Research and Theory, 22(2): 289-317.

Holum, Marthe L. \& Jakobsen, Tor G. 2016 Inter-Municipal Cooperation and Satisfaction with Services: Evidence from the Norwegian Citizen Study. International Journal of Public Administration, 39(8): 597-609.

Holzer, Marc, Charbonneau, Etienne \& Kim, Younhee. 2009. "Mapping the terrain of public service quality improvements: twenty-five years of trends and practices in the United States." International Review of Administrative Sciences 75(3): 403-418.

Holzer, Marc \& Fry, John C. 2011. Shared services and municipal consolidation: A critical analysis. Washington DC: Public Technology Institute.

Homsy, George C. 2018. Unlikely pioneers: creative climate change policymaking in smaller US cities, Journal of Environmental Studies and Sciences 8 (2): 121-131.

Homsy, George C. \& Warner, Mildred E. 2014. Intermunicipal Cooperation: The Growing Reform, pp 53-65 in The Municipal Yearbook 2014, Washington, DC: International City County Management Association. 
Hulst, J. R. (Rudie) \& van Montfort, A.J.G.M. (André). 2012. Institutional features of intermunicipal cooperation: Cooperative arrangements and their national contexts. Public Policy and Administration 27 (2): 121-144.

Johnston, Jocelyn M. \& Girth, Amanda M., 2012. Government contracts and "managing the market" exploring the costs of strategic management responses to weak vendor competition. Administration \& Society, 44(1), pp.3-29.

Kim, Yunji. 2018. "Can Alternative Service Delivery Save Cities after the Great Recession? Barriers to Privatisation and Cooperation." Local Government Studies 44 (1): 44-63.

Lowery, David. 2000. "A Transactions Costs Model of Metropolitan Governance: Allocation Versus Redistribution in Urban America." Journal of Public Administration Research and Theory (10)1: 49-78.

Miranda, Rowan \& Lerner, Allan. 1995. "Bureaucracy, organizational redundancy, and the privatization of public services." Public Administration Review. 55(2): 193-200.

Niaounakis, Thomas \& Blank, Jos. 2017. "Inter-Municipal Cooperation, Economies of Scale and Cost Efficiency: An Application of Stochastic Frontier Analysis to Dutch Municipal Tax Departments. "Local Government Studies 43(4): 533-54.

Ostrom, Elinor. 1990. Analyzing Collective Action. Agricultural Economics 41(S1): 155-66.

Ostrom, Elinor. 1972. Metropolitan Reform: Propositions Derived From Two Traditions. Social Science Quarterly 53(3): 474-493.

Ostrom, Elinor \& Ostrom, Vincent. 1977. Public Economy Organization and Service Delivery. Presented at the Financing the Regional City Project meeting of the Metropolitan Fund, University of Michigan, Dearborn, MI, October 1977. http://hdl.handle.net/10535/732

Ostrom, Vincent, Tiebout, Charles M. \& Warren, Robert. 1961. The organization of government in metropolitan areas: A theoretical inquiry. American Political Science Review 55(4): 831-842.

Pérez-López, Gemma, Prior, Diego \& Zafra-Gómez, José L. 2018. “Temporal Scale Efficiency in DEA Panel Data Estimations. An Application to the Solid Waste Disposal Service in Spain." Omega 76: 18-27.

Pérez-López, Gemma, Prior, Diego, Zafra-Gómez, José Luis \& Plata-Díaz, Ana María. 2016. Cost efficiency in municipal solid waste service delivery. Alternative management forms in relation to local population size. European Journal of Operational Research, 255: 583-592.

Rizzo, Victoria M. \& Rowe, Jeannine M.. 2016. "Cost-Effectiveness of Social Work Services in Aging: An Updated Systematic Review." Research on Social Work Practice 26(6): 653-667.

Rockefeller Institute of Government, Benjamin Center, and the Center for Technology in Government. 2017. "A Review of the Plans Submitted Under the State County-Wide Shared Service Imitative.” Retrieved from:https://www.dos.ny.gov/lg/pdf/Rockefeller_CWSSI_Report.pdf

Scott, Tyler. 2015. Does Collaboration Make Any Difference? Linking Collaborative Governance to Environmental Outcomes. Journal of Policy Analysis and Management 34(3): 537-566.

Sørensen, Rune J. 2007. Does Dispersed Public Ownership Impair Efficiency? The Case of Refuse Collection in Norway. Public Administration 85(4): 1045-58.

Soukopová, Jana \& Klimovský, Daniel. 2016. "Local Governments and Local Waste Management in the Czech Republic: Producers or Providers?" Journal of Public Administration and Policy 9(2): 217-37.

Soukopová, Jana, Ochrana, František, Klimovský, Daniel \& Meričková, Beáta Mikušová. 2016. Factors influencing the efficiency and effectiveness of municipal waste management expenditure. Lex Localis, Journal of local Self-Government, 14(3): 359-278. 
Soukopová, Jana \& Vaceková, Gabriela. 2018. "Internal Factors of Intermunicipal Cooperation: What Matters Most and Why?" Local Government Studies 44(1): 10526.

Stevens, Barbara J. 1978. "Scale, Market Structure, and the Cost of Refuse Collection." The Review of Economics and Statistics (60)3):438-448.

Van Ryzin, Gregg G. 2004. "Expectations, Performance, and Citizen Satisfaction with Urban Services." Journal of Policy Analysis and Management 23(3): 433-448.

Warner, Mildred E. 2011. "Competition or Cooperation in Urban Service Delivery?" Annals of Public and Cooperative Economics, 82(4): 421-435.

Warner, Mildred E. \& Hebdon, Robert. 2001 "Local Government Restructuring: Privatization and Its Alternatives," Journal of Policy Analysis and Management 20(2): 315-336.

Warner, Mildred E., Homsy, George C. \& Morken, Lydia M. 2017. Planning for Aging in Place: Stimulating a Market and Government Response, Journal of Planning Education and Research, 37(1): 29-42.

Williamson, Oliver E. (1967). Hierarchical Control and Optimum Firm Size. Journal of Political Economy 75(2): 123-138.

Zafra-Gómez, Jose Luis, Prior, Diego, Plata-Díaz, Ana Maria \& López-Hernández, Antonio M. 2013. Reducing costs in times of crisis: Delivery forms in small and medium sized local governments' waste management services. Public Administration, 91(1): 51-68.

Zeemering, Eric. 2018. "Do Interlocal Contracts Seek Collaborative Efficiency? An Investigation of Policy Service Delivery in California Cities." Public Management Review. DOI: 10.1080/14719037.2018.1538424 
Appendix: Table 1. Descriptive Statistics of Model Variables

\begin{tabular}{|c|c|c|c|c|c|}
\hline \multicolumn{6}{|c|}{ Police } \\
\hline $\mathrm{N}=355$ & Total Cost & Shared & Population & Density & City \\
\hline Mean & 2364338 & 0.29 & 24434 & 1618 & 0.09 \\
\hline Stan.Dev & 6003993 & 0.46 & 82894 & 1858 & 0.29 \\
\hline \multicolumn{6}{|c|}{ Library } \\
\hline $\mathrm{N}=346$ & Total Cost & Shared & Population & Density & City \\
\hline Mean & 199711 & 0.52 & 14511 & 1069 & 0.06 \\
\hline Stan.Dev & 889495 & 0.5 & 59130 & 1699 & 0.24 \\
\hline \multicolumn{6}{|c|}{ Roads and Highways } \\
\hline $\mathrm{N}=904$ & Total Cost & Shared & Population & Density & City \\
\hline Mean & 1555108 & 0.48 & 14562 & 1056 & 0.04 \\
\hline Stan.Dev & 4684683 & 0.5 & 61720 & 1915 & 0.2 \\
\hline \multicolumn{6}{|c|}{ Solid Waste Management } \\
\hline $\mathrm{N}=472$ & Total Cost & Shared & Population & Density & City \\
\hline Mean & 1038545 & 0.26 & 16330 & 1498 & 0.07 \\
\hline Stan.Dev & 5975984 & 0.44 & 64925 & 2297 & 0.25 \\
\hline \multicolumn{6}{|c|}{ Sewer } \\
\hline $\mathrm{N}=466$ & Total Cost & Shared & Population & Density & City \\
\hline Mean & 1399224 & 0.37 & 17477 & 1390 & 0.08 \\
\hline Stan.Dev & 9839988 & 0.48 & 71748 & 1758 & 0.27 \\
\hline \multicolumn{6}{|c|}{ Elder services } \\
\hline $\mathrm{N}=355$ & Total Cost & Shared & Population & Density & City \\
\hline Mean & 321547 & 0.37 & 29808 & 978 & 0.04 \\
\hline Stan.Dev & 1282749 & 0.48 & 97769 & 1728 & 0.21 \\
\hline \multicolumn{6}{|c|}{ Fire } \\
\hline $\mathrm{N}=624$ & Total Cost & Shared & Population & Density & City \\
\hline Mean & 496577 & 0.54 & 7177 & 1139 & 0.06 \\
\hline Stan.Dev & 2165091 & 0.5 & 17235 & 2002 & 0.23 \\
\hline \multicolumn{6}{|c|}{ Water } \\
\hline $\mathrm{N}=567$ & Total Cost & Shared & Population & Density & City \\
\hline Mean & 718767 & 0.38 & 13542 & 1168 & 0.06 \\
\hline Stan.Dev & 1874739 & 0.49 & 59858 & 1647 & 0.24 \\
\hline \multicolumn{6}{|c|}{ Youth recreation } \\
\hline $\mathrm{N}=590$ & Total Cost & Shared & Population & Density & City \\
\hline Mean & 61918 & 0.49 & 15167 & 973 & 0.05 \\
\hline Stan.Dev & 179904 & 0.5 & 59056 & 1569 & 0.22 \\
\hline \multicolumn{6}{|c|}{ Economic development and promotion } \\
\hline $\mathrm{N}=135$ & Total Cost & Shared & Population & Density & City \\
\hline Mean & 196396 & 0.37 & 31778 & 1507 & 0.11 \\
\hline Stan.Dev & 790009 & 0.48 & 102021 & 2340 & 0.31 \\
\hline \multicolumn{6}{|c|}{ Ambulance/EMS } \\
\hline $\mathrm{N}=290$ & Total Cost & Shared & Population & Density & City \\
\hline Mean & 69874 & 0.59 & 10527 & 1074 & 0.04 \\
\hline Stan.Dev & 246800 & 0.49 & 47171 & 2145 & 0.21 \\
\hline \multicolumn{6}{|c|}{ Zoning and planning } \\
\hline $\mathrm{N}=683$ & Total Cost & Shared & Population & Density & City \\
\hline Mean & 135227 & 0.11 & 14950 & 1126 & 0.05 \\
\hline Stan.Dev & 1128541 & 0.31 & 65004 & 1945 & 0.21 \\
\hline
\end{tabular}

Police 